\title{
Differences in medical treatment and clinical characteristics between men and women with heart failure - a single-centre multivariable analysis
}

\author{
Helena Norberg ${ }^{1,2}$ (D) Veronica Pranic ${ }^{1} \cdot$ Ellinor Bergdahl $^{1} \cdot$ Krister Lindmark $^{1}$ (D)
}

Received: 23 June 2019 / Accepted: 10 October 2019 / Published online: 3 January 2020

(C) The Author(s) 2020

\begin{abstract}
Purpose The aims of this study were to examine sex differences in a heart failure population with regards to treatment and patient characteristics and to investigate the impact of sex on achieved doses of heart failure medications.

Methods and results A total of 1924 patients with heart failure in a regional hospital were analysed, 622 patients had ejection fraction $\leq 40 \%$ of which $30 \%$ were women. In patients with reduced ejection fraction, women were older (79 \pm 11 vs. $74 \pm 12$ years, $P<0.001$ ), had lower body weight ( $70 \pm 17 \mathrm{vs} .86 \pm 18 \mathrm{~kg}, P<0.001)$, lower estimated glomerular filtration rate (eGFR) $(49 \pm 24$ vs. $71 \pm 30 \mathrm{ml} / \mathrm{min}, P<0.001)$ and received lower doses of heart failure medications than men. Multivariable linear regression on patients with reduced ejection fraction showed that sex was not associated with achieved dose of any heart failure medication. For angiotensin-converting enzyme inhibitors and angiotensin receptor blockers associated factors were eGFR, systolic blood pressure, age, ejection fraction, and heart rate. For beta-blockers associated factors were body weight, atrial fibrillation and age. For mineralocorticoid receptor antagonists associated factors were eGFR, serum potassium, age, systolic blood pressure, ejection fraction and heart rate.

Conclusion Women with heart failure and reduced ejection fraction were prescribed lower doses of heart failure medications, were older, had worse renal function, and lower body weight than men. Sex was not independently associated with achieved doses of heart failure medications, instead age, renal function and body weight explained the differences in treatment.
\end{abstract}

Keywords Heart failure $\cdot \mathrm{HFrEF} \cdot$ Target dose $\cdot$ Sex differences

\section{Introduction}

In heart failure $(\mathrm{HF})$ with reduced ejection fraction (HFrEF) guidelines recommend uptitration of angiotensin-converting enzyme inhibitors (ACE-I) or angiotensin receptor blockers (ARB), as well as beta-blockers and mineralocorticoid receptor antagonists (MRA) to specified target doses [1, 2]. Target doses are based on landmark trials in which the representation

Electronic supplementary material The online version of this article (https://doi.org/10.1007/s00228-019-02782-2) contains supplementary material, which is available to authorized users.

Krister Lindmark

krister.lindmark@umu.se

1 Department of Public Health and Clinical Medicine, Umeå University, S-901 87 Umeå, Sweden

2 Department of Pharmacology and Clinical Neuroscience, Umeå University, Umeå, Sweden of women has been between 20 and 25\% [3-11]. There is a large discrepancy in the proportion of women represented in randomized landmark studies compared to real-world HF populations. The proportion of women in real-world populations with HF is between $47-53 \%$ and $36-42 \%$ for HFrEF [12-16] and in surveys or registries with a more selected patient population the proportion of women with $\mathrm{HF}$ is $28 \%$ [17] and for HFrEF between 21 and 23\% [17, 18]. This discrepancy is a contributing factor to the present knowledge gap of how to treat women with HF. The knowledge gap was recently highlighted in two studies where the proportion of women enrolled in HF trials from 2001 to 2016 were investigated $[19,20]$. These studies confirmed that HFrEF trials included only $24 \%$ women.

Studies have also shown that women are prescribed standard HF therapies to lesser extent and in lower doses compared to men [15, 21-23], and the reasons for this are still unknown. Previous studies were conducted in a wide range of settings, in different countries. Study design varies from 
large prospective multicentre surveys to observational singlecentre studies, based on registries or clinical data, both on reduced and preserved HF. The majority of the studies were performed about two decades ago, but they all show that women receive less evidence-based treatment than men. However, these studies do not include a multivariable analysis that includes biological differences between men and women with HF. The aims of this study were to examine sex differences in a HF population with regards to treatment and patient characteristics, as well as to investigate if sex is an independent predictor for achieved doses of ACE-I/ARB, betablockers and MRA.

\section{Methods}

\section{Study population and data collection}

All patients alive at March 2016 living within the catchment area of Umeå University Hospital, Sweden with a HF diagnosis and at least one visit to the cardiology or internal medicine department between January 2010 and March 2016 were included. The HF diagnosis was derived from medical records as primary or secondary diagnosis according to the International Classification of Diseases, 10th revision codes I50.X, I42.X, I11.0. All diagnoses had been signed or countersigned by a specialist in cardiology or internal medicine. For the diagnosis of HFrEF, the patients also needed to have an ejection fraction of $\leq 40 \%$. The diagnosis of HF with preserved or mid-range ejection fraction was not validated by any other means. Only patients with HFrEF were included in the multivariable analysis.

Data collection were performed between 1 June 2015 and 31 March 2016 from the medical records according to a standardized form consisting of clinical characteristics, laboratory data, medications, electrocardiography and echocardiography parameters. The latest available data were used in the analyses. We used the Cockcroft-Gault formula to calculate estimated glomerular filtration rate (eGFR).

\section{Setting}

Umeå University Hospital is serving approximately 150,000 residents with a mixed rural and urban population in Northern Sweden. The hospital represents the only cardiology clinic in the region. According to local guidelines, all patients with suspected heart failure should be referred to the cardiology clinic for diagnosis and uptitration of heart failure medications. The hospital uses an electronically medical records system (NCS Cross) from which patients with heart failure have been identified and data manually collected. This study complied with the Declaration of Helsinki and has received ethical approval by the Regional Ethical Review Board in Umeå, Sweden.

\section{Statistical analysis}

Patient characteristics were analysed with t-, chi-square, and Mann Whitney U test as appropriate. Continuous variables were reported as mean and standard deviation, or, as median and interquartile range if non-normally distributed. Categorical variables were reported as numbers and percentages.

To determine factors predicting the percentage of achieved target dose of ACE-I/ARB, beta-blocker and MRA in the HFrEF population (ejection fraction $\leq 40 \%$ ), we used a manual stepwise backward multivariable linear regression model. Percentage of achieved target doses was calculated as the latest prescribed dose divided by the target dose of the individual substance, according to European Society of Cardiology guidelines [1], for each patient separately as a continuous variable. Target doses are defined in Appendix. The selected target doses were in strict accordance to the guidelines and did not consider individual decisions for lower target doses due to kidney function, body weight or other reasons.

The linear regression models were constructed with initial bivariate analyses of the most relevant patient characteristics: age, sex, body weight, eGFR, systolic blood pressure, heart rate, ejection fraction, N-terminal pro-B-type natriuretic peptide (NTproBNP), serum potassium, atrial fibrillation, coronary artery disease, diabetes and hypertension. Variables were reviewed to explore distribution, outliers and dependency. Distribution and outliers were reviewed with histograms for each variable and with histograms and Normal P-P plots of the residuals for each analysis. To review dependence, we used Pearson's correlation between dependent and independent variables one by one. We also applied Pearson's correlation analysis with eGFR, body weight, age and creatinine. Furthermore, as part of the linear regression analysis, we assessed multicollinearity with tolerance and Variance Inflation Factor (VIF). If dependency was apparent, one of the variables was selected and the others omitted (e.g. body weight and height versus body mass index). Five percent of eGFR values were outliers $(>130 \mathrm{ml} / \mathrm{min})$ due to extreme body weight or muscle mass. We consequently truncated all eGFR values over $130 \mathrm{ml} / \mathrm{min}$ to this maximum limit to reduce the statistical impact of those values in the multivariable analyses. Variables with a significance level less than 0.25 in the bivariate analyses were included in the multivariable linear regression models, where manual stepwise backward analysis was performed to determine the final prediction models. Interaction terms for sex*age, sex*body weight and sex*eGFR were also included in the multivariable analyses. Sex was kept in the backward analysis, even if nonsignificant, since it was central to our aims. $P$ values less than 0.05 were 
considered statistically significant in the final models. IBM SPSS Statistics, Version 25.0 (Armonk, NY: IBM Corp.) was used for all analyses.

\section{Results}

In total, the HF population of Umeå University Hospital consisted of 1924 patients ( $43 \%$ women). Of these, 622 patients (30\% women) had an ejection fraction of $\leq 40 \%$. A total of 29 patients with HFrEF had received their diagnosis within 3 months of data collection and possibly did not have ample time for complete uptitration. Seven of these had received maximum target dose ACE-I/ARB, and nine had received maximum target dose beta blockers. Patient characteristics of the two populations are shown in Table 1. Women were significantly older, had lower body weight, lower eGFR, higher systolic blood pressure, less coronary artery disease, lower doses of HF medications and less devices than men in both the HFrEF and total HF population. Women in the total HF population also had significantly higher heart rate and ejection fraction compared to men, which was not shown among patients with HFrEF.

In the HFrEF population, ACE-I/ARB and beta-blockers were prescribed to approximately $90 \%$ and MRA to $47 \%$ of patients. Men were prescribed significantly higher doses of ACE-I/ARB and MRA compared to women, while no differences in beta-blocker dose were shown (Fig. 1A). Patients were prescribed target doses of ACE-I/ARB, beta-blockers and MRA in full extent in 37\%, 29\% and 4\%, respectively (Fig. 1B). The proportion of patients achieving different dosing levels of ACE-I/ARB, beta-blockers and MRA are presented in Fig. 2.

The linear regression models for ACE-I/ARB, betablockers and MRA in patients with HFrEF are shown in Table 2. Sex was not an independent predictor for achieved proportion of target dose ACE-I/ARB, beta-blockers or MRA. Systolic blood pressure $(p=0.012)$ and eGFR $(p<0.001)$ were independently associated with higher proportion of target dose ACE-I/ARB, while age $(\mathrm{p}<0.001)$, ejection fraction $(p=0.028)$ and heart rate $(p=0.006)$ were negatively associated. For beta-blockers, body weight $(p=0.002)$ and atrial fibrillation $(p=0.018)$ were independently associated with higher proportion of target dose, while age $(p<0.001)$ was negatively associated. Heart rate was not associated with achieved beta-blocker dose. For MRA, eGFR $(p<0.001)$ and serum potassium level $(\mathrm{p}=0.001)$ were independently associated with higher proportion of target dose, while age $(p=0.012)$, systolic blood pressure $(p=0.038)$, ejection fraction $(p=0.001)$ and heart rate $(p=0.001)$ were negatively associated. None of the interaction terms were significant in the multivariable analyses and were omitted from the final models.

\section{Discussion}

Women with HF were older, had lower body weight and worse renal function than men. Women were also less likely to present with HFrEF and women with HFrEF received ACE-I/ARB and MRA to a lesser extent and in lower doses compared to men. Sex did not predict achieved dose for ACE-I/ARB, beta-blockers or MRA in patients with HFrEF. Factors associated with achieved doses were age, renal function and body weight.

Age was a significant associated factor for achieved doses of all three groups of HF medications in HFrEF. This is expected since older patients often are frailer and with more comorbidities, which reduces the tolerance of HF medications. Also, the increased percentage body fat in elderly patients can reduce the tolerance of HF drugs [24, 25].

Body weight was associated with achieved target dose for beta-blockers, but not for ACE-I/ARB or MRA in HFrEF. This may be explained as a probable dependency matter as body weight is a factor in the Cockcroft-Gault formula which was used to estimate GFR. Renal function was in turn a predictor for achieved doses of ACE-I/ARB and MRA. Since beta-blockers are, in general, not as dependent on renal function for excretion as ACE-I/ARB and MRA, body weight is probably a more important factor for tolerance of beta-blocker dose.

Systolic blood pressure, heart rate and ejection fraction were associated factors for both ACE-I/ARB and MRA but not for beta-blockers in HFrEF. Why heart rate did not predict achieved beta-blocker dose may be because heart rate was based on the latest available measurement; hence after uptitration and since the heart rate is often the limiting factor in the uptitration, patients with both high and low doses of beta blockade may end up with similar heart rate.

Previous studies support that MRAs are often underused in clinical practice [18, 26-28], especially in patients with moderately impaired renal function $[26,28]$. Guidelines are unclear about how to best manage patients who do not tolerate evidence-based target doses of ACE-I/ARB and beta-blockers but who are still symptomatic and have reduced ejection fraction. Should an MRA be added at the expense of lower doses of ACE-I/ARB and beta-blockers? This is also important with novel HF medications such as sacubitril-valsartan where the old and frail would not receive treatment if adherence to the PARADIGM-HF trial [11] (Prospective Comparison of Angiotensin Receptor-Neprilysin Inhibitor with ACE-I to Determine Impact on Global Mortality and Morbidity in Heart Failure) inclusion criteria is strict [23, 29, 30].

There are some established sex differences associated with HF which our study also confirm; women are older and are less likely to develop HFrEF than men [15, 22, $31,32]$. In HF aetiology, women more often have a history of hypertension, while ischemic heart disease is less 
Table 1 Patient characteristics by sex

\begin{tabular}{|c|c|c|c|c|c|c|}
\hline \multirow[b]{2}{*}{ Characteristics } & \multicolumn{3}{|c|}{ Total HF population } & \multicolumn{3}{|c|}{ HFrEF $(E F \leq 40 \%)$ population } \\
\hline & $\begin{array}{l}\text { Women } \\
(n=830)\end{array}$ & $\begin{array}{l}\text { Men } \\
(n=1094)\end{array}$ & $\begin{array}{l}p \\
\text { value }\end{array}$ & $\begin{array}{l}\text { Women } \\
(n=188)\end{array}$ & $\begin{array}{l}\text { Men } \\
(n=434)\end{array}$ & $\begin{array}{l}p \\
\text { value }\end{array}$ \\
\hline Age - years & $79.0 \pm 12.1$ & $74.0 \pm 12.4$ & $<0.001$ & $79.1 \pm 11.1$ & $74.3 \pm 11.7$ & $<0.001$ \\
\hline Body weight $-\mathrm{kg}$ & $71.7 \pm 17.8$ & $86.7 \pm 18.0$ & $<0.001$ & $69.6 \pm 16.5$ & $85.5 \pm 17.6$ & $<0.001$ \\
\hline Height $-\mathrm{cm}$ & $160.8 \pm 6.8$ & $175.9 \pm 7.1$ & $<0.001$ & $161.0 \pm 6.5$ & $175.4 \pm 7.4$ & $<0.001$ \\
\hline Body mass index $-\mathrm{kg} / \mathrm{m}^{2}$ & $27.7 \pm 6.3$ & $28.0 \pm 5.3$ & 0.33 & $26.8 \pm 5.8$ & $27.7 \pm 5.1$ & 0.047 \\
\hline $\begin{array}{l}\text { Serum creatinine - } \\
\mu \mathrm{mol} / \mathrm{L}^{*}\end{array}$ & $97.1 \pm 57.7$ & $\begin{array}{c}113.6 \pm \\
77.3\end{array}$ & $<0.001$ & $\begin{array}{c}104.1 \pm \\
50.5\end{array}$ & $\begin{array}{c}111.9 \pm \\
68.1\end{array}$ & 0.16 \\
\hline eGFR - ml/min & $54.3 \pm 26.3$ & $71.9 \pm 30.4$ & $<0.001$ & $49.2 \pm 24.4$ & $70.8 \pm 30.4$ & $<0.001$ \\
\hline $\begin{array}{l}\text { Systolic blood pressure - } \\
\mathrm{mmHg}\end{array}$ & $132 \pm 21$ & $127 \pm 19$ & $<0.001$ & $129 \pm 20$ & $124 \pm 18$ & 0.001 \\
\hline $\begin{array}{l}\text { Diastolic blood pressure - } \\
\mathrm{mmHg}\end{array}$ & $73 \pm 12$ & $75 \pm 11$ & 0.03 & $73 \pm 11$ & $74 \pm 11$ & 0.28 \\
\hline Heart rate - beats $/ \mathrm{min}$ & $76 \pm 17$ & $73 \pm 16$ & $<0.001$ & $77 \pm 15$ & $75 \pm 16$ & 0.12 \\
\hline Ejection fraction - \% & $50.1 \pm 10.7$ & $44.8 \pm 11.5$ & $<0.001$ & $34.4 \pm 5.9$ & $33.3 \pm 6.3$ & 0.04 \\
\hline $\begin{array}{l}\text { NTproBNP, median (IQR) } \\
\quad-\text { pg/ml }\end{array}$ & $\begin{array}{l}1084 \\
(392-25- \\
10)\end{array}$ & $\begin{array}{l}927 \\
\quad(331-21- \\
77)\end{array}$ & 0.01 & $\begin{array}{l}1884 \\
\quad(578-40- \\
80)\end{array}$ & $\begin{array}{l}1401 \\
(579-31- \\
19)\end{array}$ & 0.10 \\
\hline $\begin{array}{l}\text { Serum potassium - } \\
\mathrm{mmol} / \mathrm{L}\end{array}$ & $4.22 \pm 0.4$ & $4.30 \pm 0.4$ & $<0.001$ & $4.26 \pm 0.4$ & $4.35 \pm 0.4$ & 0.02 \\
\hline Hemoglobin - g/L & $\begin{array}{c}127.5 \pm \\
14.0\end{array}$ & $\begin{array}{c}136.8 \pm \\
17.3\end{array}$ & $<0.001$ & $\begin{array}{c}126.7 \pm \\
13.1\end{array}$ & $\begin{array}{c}137.0 \pm \\
16.8\end{array}$ & $<0.001$ \\
\hline \multicolumn{7}{|l|}{ Medical history, n (\%) } \\
\hline Atrial fibrillation & $422(51)$ & $563(52)$ & 0.79 & $88(47)$ & $213(49)$ & 0.60 \\
\hline Coronary artery disease & $294(35)$ & $525(48)$ & $<0.001$ & $72(38)$ & $243(56)$ & $<0.001$ \\
\hline Diabetes & $174(21)$ & $251(23)$ & 0.30 & $43(23)$ & $107(25)$ & 0.63 \\
\hline Hypertension & $619(75)$ & $793(73)$ & 0.30 & $126(67)$ & $297(68)$ & 0.73 \\
\hline $\begin{array}{l}\text { Previous HF } \\
\text { hospitalization }\end{array}$ & $328(40)$ & 407 (37) & 0.30 & $96(51)$ & $215(50)$ & 0.73 \\
\hline \multicolumn{7}{|l|}{$\begin{array}{l}\text { Medications and devices, } \mathrm{n} \\
(\%)\end{array}$} \\
\hline ACE-I or ARB & $692(83)$ & $965(88)$ & 0.002 & $164(87)$ & $403(93)$ & 0.02 \\
\hline Beta-blocker & $686(83)$ & $943(86)$ & 0.03 & $169(90)$ & $395(91)$ & 0.66 \\
\hline $\begin{array}{l}\text { Mineralocorticoid receptor } \\
\text { antagonist }\end{array}$ & $254(31)$ & $392(36)$ & 0.02 & $76(40)$ & $219(51)$ & 0.02 \\
\hline Loop diuretics & $541(65)$ & $621(57)$ & $<0.001$ & $138(73)$ & $259(60)$ & 0.001 \\
\hline Digitalis & $109(13)$ & $119(11)$ & 0.13 & $27(14)$ & $50(12)$ & 0.32 \\
\hline $\begin{array}{l}\text { Implantable } \\
\text { cardioverter-- } \\
\text { defibrillator }^{\dagger}\end{array}$ & $28(3)$ & $108(10)$ & $<0.001$ & $14(7)$ & $78(18)$ & 0.001 \\
\hline $\begin{array}{l}\text { Cardiac resynchronization } \\
\text { therapy }^{\dagger}\end{array}$ & $30(4)$ & $102(9)$ & $<0.001$ & $19(10)$ & $71(16)$ & 0.04 \\
\hline
\end{tabular}

$A C E-I$, angiotensin-converting enzyme inhibitor; $A R B$, angiotensin receptor blocker; $E F$, ejection fraction; $e G F R$, estimated glomerular filtration rate; $H F$, heart failure; $H F r E F$, heart failure with reduced ejection fraction; $I Q R$, interquartile range; $N T$ TPoBNP, N-terminal pro-B-type natriuretic peptide

${ }^{*}$ To convert the values for creatinine to $\mathrm{mg} / \mathrm{dl}$, divide by 88.4

${ }^{\dagger}$ Including patients with cardiac resynchronization therapy defibrillator (CRT-D)

common than in men. Women also have a different body fat composition compared to men, which together with other biological aspects, such as longer gut transit time, higher CYP3A4 enzyme activity, lower renal blood flow, GFR and body weight, can affect both the pharmacodynamics and pharmacokinetics of HF drugs [24, 25].
Compared to previous studies on sex differences in HF treatment $[15,21,22]$, this study includes a multivariable analysis to investigate possible other reasons than gender bias to explain treatment differences and offers updated knowledge of treatment differences. We hope this study can contribute to increased attention of a lower tolerance 

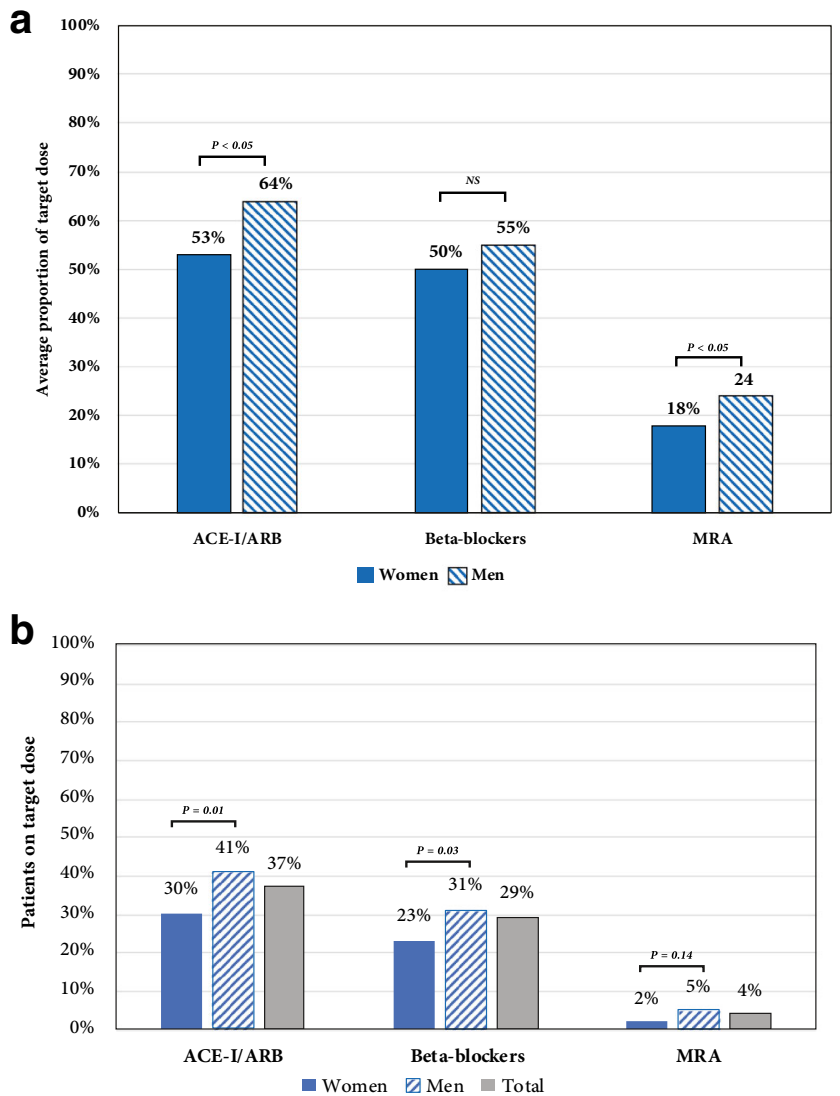

Fig. 1 Patients with heart failure and ejection fraction $\leq 40 \%$ with a) Average proportion of target dose of ACE inhibitors (ACE-I) or angiotensin receptor blockers (ARB), beta-blockers and mineralocorticoid receptor antagonists (MRA), and b) Total proportion of patients on target dose of ACE-I/ARB, beta-blockers and MRA, according to sex. $p$ values refer to differences between men and women. NS; Not significant

of HF medications among female and frail patients and better guidance for clinicians. We did not find a significant association between sex and achieved doses in the HFrEF population which indicates that there is not a clear gender bias in HF treatment. However, the biological differences between men and women may explain differences in pharmacological tolerance and highlights the need for clinical trials that include patients with characteristics that better resemble the real-world HF population.

Most HF trials have aimed for the highest tolerable dose of HF medications, but some newer trials, such as the PARADIGM-HF study [11], only included patients who tolerated a fixed target dose during a run-in phase before randomization. When strict target doses are used as inclusion criteria, together with the shown differences between male and female patients in tolerance of HF medications, it is pharmacologically reasonable that elderly, frail and female patients are underrepresented in clinical trials. Previous studies have shown that approximately $50-75 \%$ of patients tolerate target doses of $\mathrm{HF}$
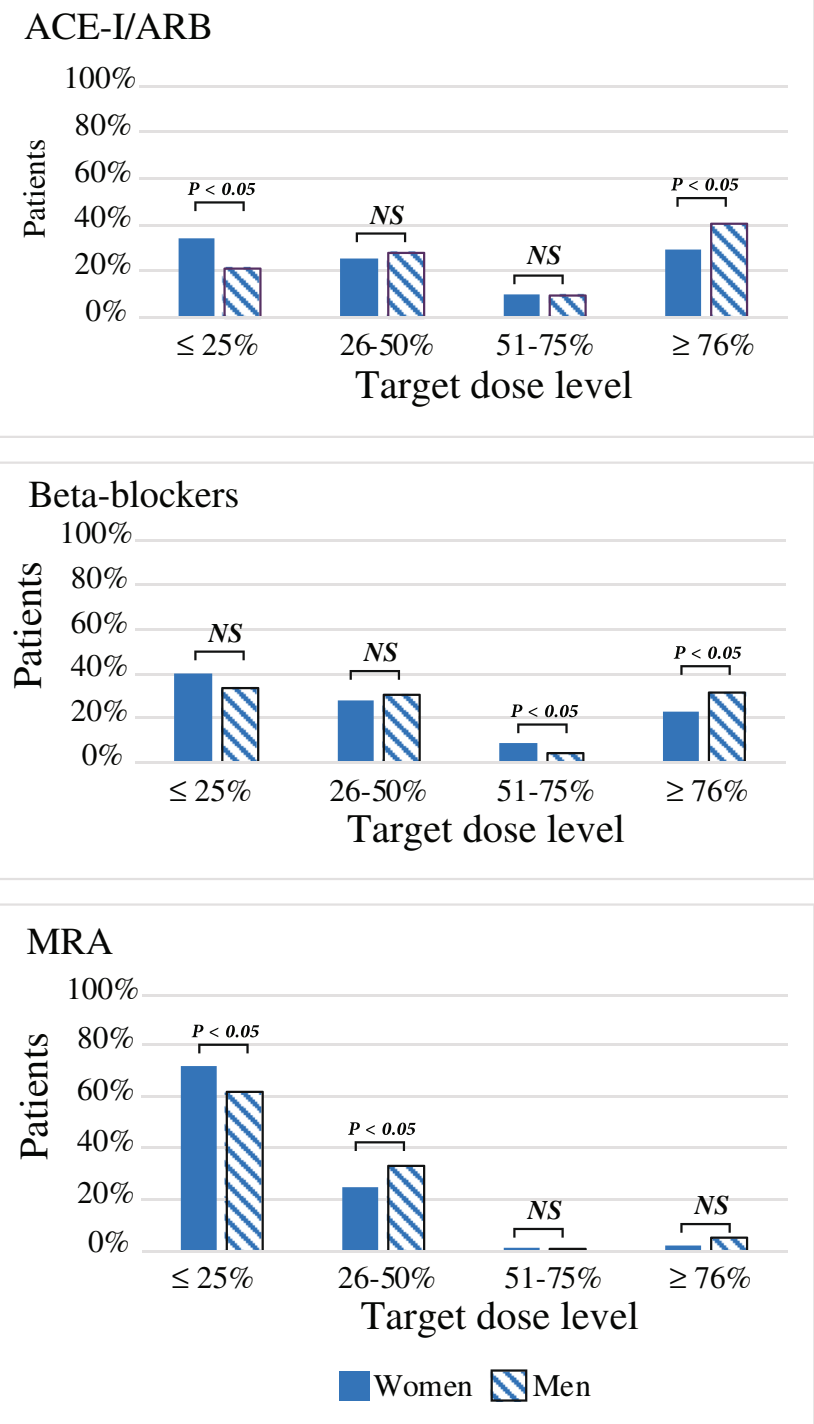

Fig. 2 Proportion of patients with heart failure and ejection fraction $\leq$ $40 \%$ according to target dose level of ACE inhibitors (ACE-I) or angiotensin receptor blockers (ARB), beta-blockers and mineralocorticoid receptor blockers (MRA). NS; Not significant

medications in clinical trials $[3,4,8,10,11]$, compared with $7-$ $50 \%$ of HFrEF patients in clinical practice [18, 29, 33, 34]. To gain more knowledge of how to offer the most appropriate HF treatment to the elderly and women, we need to increase the representation of these patients in clinical trials [35].

\section{Limitations}

The study only included a single-centre cohort, which limits the external validity of the results. On the other hand, it is based on a HF population without exclusion of old, frail patients with dementia or other comorbidities, which is especially important when analysing sex differences. The data collection period was relatively long (June 2015 to March 2016), as 
Table 2 Bivariate and final regression models of percentage of achieved target doses of ACE-I/ARB, Beta-blockers and MRA in patients with heart failure and ejection fraction $\leq 40 \%$

\section{Bivariate models*}

ACE-I/ARB

Variables

$\mathrm{Sex}^{\dagger}$

$\mathrm{B}$

Age

Body weight

eGFR

Systolic blood pressure

Heart rate

Ejection fraction

NTproBNP

Serum potassium

Atrial fibrillation

Coronary artery disease

Diabetes

Hypertension
0.107

$-0.011$

0.005

0.005

0.001

$-0.003$

$-0.003$

$-0.000$

0.066

$-0.079$

$-0.017$

$-0.024$

$-0.029$

Final regression models*,‡

\section{ACE-I/ARB}

$\begin{array}{ll}\text { Sex }^{\dagger} & \text { B } \\ \text { Age } & -0.002 \\ \text { eGFR } & -0.006 \\ & 0.003\end{array}$

95\% CI $\quad p$ value

-0.067 to 0.0640 .959

-0.009 to $-0.003<0.001$

Systolic blood pressure 0.002

Heart rate $\quad-0.002$

Ejection fraction $\quad-0.005$

Adjusted $\mathrm{R}^{2}=0.177$

Beta-blockers

$\begin{array}{llll} & \text { B } & 95 \% \text { CI } & p \text { value } \\ \text { Sex }^{\dagger} & -0.021 & -0.085 \text { to } 0.043 & 0.527 \\ \text { Age } & -0.007 & -0.010 \text { to }-0.005 & <0.001 \\ \text { Body weight } & 0.002 & 0.001 \text { to } 0.004 & 0.002 \\ \text { Atrial fibrillation } & 0.067 & 0.012 \text { to } 0.123 & 0.018\end{array}$

Adjusted $\mathrm{R}^{2}=0.089$

MRA

$\begin{array}{llll} & \text { B } & 95 \% \text { CI } & p \text { value } \\ \text { Sex }^{\dagger} & -0.040 & -0.088 \text { to } 0.009 & 0.108 \\ \text { Age } & -0.003 & -0.005 \text { to }-0.001 & 0.012 \\ \text { eGFR } & 0.002 & 0.001 \text { to } 0.003 & <0.001 \\ \text { Systolic blood pressure } & -0.001 & -0.002 \text { to } 0.000 & 0.038 \\ \text { Heart rate } & -0.001 & -0.003 \text { to } 0.000 & 0.026 \\ \text { Ejection fraction } & -0.005 & -0.008 \text { to }-0.002 & 0.001 \\ \text { Serum potassium } & 0.078 & 0.030 \text { to } 0.125 & 0.001 \\ \text { Adjusted } \mathrm{R}^{2}=0.168 & & & \end{array}$

$A C E-I$, angiotensin-converting enzyme inhibitor; $A R B$, angiotensin receptor blocker; $B$, unstandardised B-coefficients; $e G F R$, estimated glomerular filtration rate; $N T p r o B N P, \mathrm{~N}$-terminal pro-B-type natriuretic peptide; $M R A$, mineralocorticoid receptor blockers

${ }^{*} \mathrm{~N}=622, \mathrm{NTproBNP} \mathrm{N}=611$

${ }^{\dagger}$ Reference female

${ }^{\ddagger}$ Adjusted for body weight, NTproBNP, serum potassium, atrial fibrillation, coronary artery disease, diabetes, hypertension 
well as the inclusion time period of patients visiting the hospital (January 2010 to March 2016). This also affects the statistical analyses and the generalisability of the results. Furthermore, the analyses including systolic blood pressure were based on the latest available blood pressure, often measured during ongoing HF treatment, which may have influenced the results. Additionally, the HF diagnoses extracted from the medical records were not all formally validated. It is therefore possible that a minor portion of the included patients with HF and preserved ejection fraction were misdiagnosed. However, the multivariable analysis only included HFrEF patients where the echocardiography showed a reduced ejection fraction. Unfortunately, the data in the medical records did not include enough information to assess the New York Heart Association (NYHA) functional class and is why we omitted this parameter in the statistical analyses.

\section{Conclusions}

Women with heart failure and reduced ejection fraction were prescribed lower doses of evidence-based heart failure medications. Women with heart failure were older, had worse renal function and lower body weight than men. Sex was not independently associated with achieved doses of heart failure medications; instead age, renal function and body weight explained the differences in treatment in patients with heart failure and reduced ejection fraction.

Acknowledgements Open access funding provided by Umeå University.

Funding Information This work was supported by the Heart Foundation of Northern Sweden.

\section{Compliance with ethical standards}

Conflicts of interest The authors declare that they have no conflict of interest.

Open Access This article is distributed under the terms of the Creative Commons Attribution 4.0 International License (http:// creativecommons.org/licenses/by/4.0/), which permits unrestricted use, distribution, and reproduction in any medium, provided you give appropriate credit to the original author(s) and the source, provide a link to the Creative Commons license, and indicate if changes were made.

\section{References}

1. Ponikowski P, Voors AA, Anker SD, Bueno H, Cleland JGF, Coats AJS, Falk V, González-Juanatey JR, Harjola VP, Jankowska EA, Jessup M, Linde C, Nihoyannopoulos P, Parissis JT, Pieske B, Riley JP, Rosano GMC, Ruilope LM, Ruschitzka F, Rutten FH, van der Meer P, ESC Scientific Document Group (2016) 2016 ESC
Guidelines for the diagnosis and treatment of acute and chronic heart failure: the task force for the diagnosis and treatment of acute and chronic heart failure of the European Society of Cardiology (ESC) developed with the special contribution of the Heart Failure Association (HFA) of the ESC. Eur Heart J 37:21292200. https://doi.org/10.1093/eurheartj/ehw128

2. Yancy CW, Jessup M, Bozkurt B, Butler J, Casey de Jr, Colvin MM, Drazner MH, Filippatos GS, Fonarow GC, Givertz MM, Hollenberg SM, Lindenfeld J, Masoudi FA, McBride P, Peterson PN, Stevenson LW, Westlake C (2017) 2017 ACC/AHA/HFSA Focused update of the 2013 ACCF/AHA guideline for the management of heart failure: a report of the American College of Cardiology/American Heart Association Task Force on Clinical Practice Guidelines and the heart failure society of America. Circulation 136:e137-e161. https://doi.org/10.1161/cir. 0000000000000509

3. (1999) The cardiac insufficiency bisoprolol study II (CIBIS-II): a randomised trial. Lancet 353: 9-13

4. (1991) Effect of enalapril on survival in patients with reduced left ventricular ejection fractions and congestive heart failure. the SOLVD investigators. N Engl J Med 325: 293-302. https://doi. org/10.1056/NEJM199108013250501.

5. (1999) Effect of metoprolol $\mathrm{CR} / \mathrm{XL}$ in chronic heart failure: metoprolol CR/XL randomised intervention trial in congestive heart failure (MERIT-HF). Lancet 353: 2001-2007

6. Packer M, Fowler MB, Roecker EB, Coats AJ, Katus HA, Krum H, Mohacsi P, Rouleau JL, Tendera M, Staiger C, Holcslaw TL, Amann-Zalan I, DeMets D, Carvedilol Prospective Randomized Cumulative Survival (COPERNICUS) Study Group (2002) Effect of carvedilol on the morbidity of patients with severe chronic heart failure: results of the carvedilol prospective randomized cumulative survival (COPERNICUS) study. Circulation 106:2194-2199

7. Cohn JN, Tognoni G (2001) A randomized trial of the angiotensinreceptor blocker valsartan in chronic heart failure. N Engl J Med 345:1667-1675. https://doi.org/10.1056/NEJMoa010713

8. Pfeffer MA, Swedberg K, Granger CB, Held P, McMurray J, Michelson EL, Olofsson B, Ostergren J, Yusuf S, Pocock S, CHARM Investigators and Committees (2003) Effects of candesartan on mortality and morbidity in patients with chronic heart failure: the CHARM-Overall programme. Lancet 362:759766

9. Pitt B, Zannad F, Remme WJ, Cody R, Castaigne A, Perez A, Palensky J, Wittes J (1999) The effect of spironolactone on morbidity and mortality in patients with severe heart failure. Randomized Aldactone Evaluation Study Investigators. N Engl J Med 341:709-717. https://doi.org/10.1056/ nejm199909023411001

10. Zannad F, McMurray JJ, Krum H, van Veldhuisen D, Swedberg K, Shi H, Vincent J, Pocock SJ, Pitt B, EMPHASIS-HF Study Group (2011) Eplerenone in patients with systolic heart failure and mild symptoms. N Engl J Med 364:11-21. https://doi.org/10.1056/ NEJMoa1009492

11. McMurray JJ, Packer M, Desai AS, Gong J, Lefkowitz MP, Rizkala AR, Rouleau JL, Shi VC, Solomon SD, Swedberg K, Zile MR, PARADIGM-HF Investigators and Committees (2014) Angiotensin-neprilysin inhibition versus enalapril in heart failure. N Engl J Med 371:993-1004. https://doi.org/10.1056/ NEJMoa1409077

12. Zarrinkoub R, Wettermark B, Wandell P et al (2013) The epidemiology of heart failure, based on data for 2.1 million inhabitants in Sweden. Eur J Heart Fail 15:995-1002. https://doi.org/10.1093/ eurjhf/hft064

13. Vasan RS, Xanthakis V, Lyass A, Andersson C, Tsao C, Cheng S, Aragam J, Benjamin EJ, Larson MG (2018) Epidemiology of left ventricular systolic dysfunction and heart failure in the Framingham study: an echocardiographic study over 3 decades. JACC 
Cardiovasc Imaging 11:1-11. https://doi.org/10.1016/j.jemg.2017. 08.007

14. Ho JE, Gona P, Pencina MJ, Tu JV, Austin PC, Vasan RS, Kannel WB, D'Agostino RB, Lee DS, Levy D (2012) Discriminating clinical features of heart failure with preserved vs. reduced ejection fraction in the community. Eur Heart J 33:1734-1741. https://doi. org/10.1093/eurheartj/ehs070

15. Opasich C, De Feo S, Ambrosio GA et al (2004) The 'real' woman with heart failure. Impact of sex on current in-hospital management of heart failure by cardiologists and internists. Eur J Heart Fail 6: 769-779. https://doi.org/10.1016/j.ejheart.2003.11.021

16. Fonarow GC, Abraham WT, Albert NM, Stough WG, Gheorghiade M, Greenberg BH, O'Connor CM, Sun JL, Yancy C, Young JB, OPTIMIZE-HF Investigators and Hospitals (2009) Age- and gender-related differences in quality of care and outcomes of patients hospitalized with heart failure (from OPTIMIZE-HF). Am J Cardiol 104:107-115. https://doi.org/10.1016/j.amjcard.2009.02. 057

17. Chioncel O, Lainscak M, Seferovic PM, Anker SD, Crespo-Leiro MG, Harjola VP, Parissis J, Laroche C, Piepoli MF, Fonseca C, Mebazaa A, Lund L, Ambrosio GA, Coats AJ, Ferrari R, Ruschitzka F, Maggioni AP, Filippatos G (2017) Epidemiology and one-year outcomes in patients with chronic heart failure and preserved, mid-range and reduced ejection fraction: an analysis of the ESC Heart Failure Long-Term Registry. Eur J Heart Fail 19: 1574-1585. https://doi.org/10.1002/ejhf.813

18. Thorvaldsen T, Benson L, Dahlstrom U, Edner M, Lund LH (2016) Use of evidence-based therapy and survival in heart failure in Sweden 2003-2012. Eur J Heart Fail 18:503-511. https://doi.org/ 10.1002/ejhf.496

19. Scott PE, Unger EF, Jenkins MR, Southworth MR, McDowell T, Geller RJ, Elahi M, Temple RJ, Woodcock J (2018) Participation of women in clinical trials supporting FDA approval of cardiovascular drugs. J Am Coll Cardiol 71:1960-1969. https://doi.org/10.1016/j. jacc.2018.02.070

20. Tahhan AS, Vaduganathan M, Greene SJ, Fonarow GC, Fiuzat M, Jessup M, Lindenfeld J, O'Connor CM, Butler J (2018) Enrollment of older patients, women, and racial and ethnic minorities in contemporary heart failure clinical trials: a systematic review. JAMA Cardiol 3:1011-1019. https://doi.org/10.1001/jamacardio.2018. 2559

21. Baumhakel M, Muller U, Bohm M (2009) Influence of gender of physicians and patients on guideline-recommended treatment of chronic heart failure in a cross-sectional study. Eur J Heart Fail 11:299-303. https://doi.org/10.1093/eurjhf/hfn041

22. Lenzen MJ, Rosengren A, Scholte op Reimer WJ et al (2008) Management of patients with heart failure in clinical practice: differences between men and women. Heart 94:e10. https://doi.org/10. 1136/hrt.2006.099523

23. Norberg H, Bergdahl E, Lindmark K (2018) Eligibility of sacubitrilvalsartan in a real-world heart failure population: a communitybased single-centre study. ESC Heart Fail 5:337-343. https://oi. org/10.1002/ehf2.12251

24. Franconi F, Brunelleschi S, Steardo L, Cuomo V (2007) Gender differences in drug responses. Pharmacol Res 55:81-95. https://doi. org/10.1016/j.phrs.2006.11.001
25. Soldin OP, Mattison DR (2009) Sex differences in pharmacokinetics and pharmacodynamics. Clin Pharmacokinet 48:143-157. https://doi.org/10.2165/00003088-200948030-00001

26. Jonsson A, Norberg H, Bergdahl E, Lindmark K (2018) Obstacles to mineralocorticoid receptor antagonists in a community-based heart failure population. Cardiovasc Ther:e12459. https://doi.org/ 10.1111/1755-5922.12459

27. Maggioni AP, Dahlstrom U, Filippatos G et al (2013) EURObservational research programme: regional differences and 1-year follow-up results of the heart failure pilot survey (ESC-HF Pilot). Eur J Heart Fail 15:808-817. https://doi.org/10.1093/eurjhf/ hft050

28. Savarese G, Carrero JJ, Pitt B et al (2018) Factors associated with underuse of mineralocorticoid receptor antagonists in heart failure with reduced ejection fraction: an analysis of 11215 patients from the Swedish Heart Failure Registry. Eur J Heart Fail. https://doi.org/ 10.1002/ejhf.1182

29. Pellicori P, Urbinati A, Shah P, MacNamara A, Kazmi S, Dierckx R, Zhang J, Cleland JGF, Clark AL (2017) What proportion of patients with chronic heart failure are eligible for sacubitril-valsartan? Eur J Heart Fail 19:768-778. https://doi.org/10.1002/ejhf.788

30. Rodrigues G, Tralhao A, Aguiar C, Freitas P, Ventosa A, Mendes M (2018) Is the PARADIGM-HF cohort representative of the realworld heart failure patient population? Rev Port Cardiol 37:491496. https://doi.org/10.1016/j.repc.2017.09.023

31. Aimo A, Vergaro G, Barison A, Maffei S, Borrelli C, Morrone D, Cameli M, Palazzuoli A, Ambrosio G, Coiro S, Savino K, Cerbai E, Marcucci R, Pedrinelli R, Padeletti L, Passino C, Emdin M (2018) Sex-related differences in chronic heart failure. Int J Cardiol 255: 145-151. https://doi.org/10.1016/j.ijcard.2017.10.068

32. Dewan P, Rorth R, Jhund PS et al (2019) Differential Impact of heart failure with reduced ejection fraction on men and women. $\mathrm{J}$ Am Coll Cardiol 73:29-40. https://doi.org/10.1016/j.jacc.2018.09. 081

33. Komajda M, Anker SD, Cowie MR, Filippatos GS, Mengelle B, Ponikowski P, Tavazzi L, QUALIFY Investigators (2016) Physicians' adherence to guideline-recommended medications in heart failure with reduced ejection fraction: data from the QUALIFY global survey. Eur J Heart Fail 18:514-522. https:// doi.org/10.1002/ejhf.510

34. de Groote P, Isnard R, Assyag P, Clerson P, Ducardonnet A, Galinier M, Jondeau G, Leurs I, Thébaut JF, Komajda M (2007) Is the gap between guidelines and clinical practice in heart failure treatment being filled? Insights from the IMPACT RECO survey. Eur J Heart Fail 9:1205-1211. https://doi.org/10.1016/j.ejheart. 2007.09.008

35. Vitale C, Fini M, Spoletini I, Lainscak M, Seferovic P, Rosano GM (2017) Under-representation of elderly and women in clinical trials. Int J Cardiol 232:216-221. https://doi.org/10.1016/j.ijcard.2017. 01.018

Publisher's note Springer Nature remains neutral with regard to jurisdictional claims in published maps and institutional affiliations. 